National and Global Petroleum Assessment

\title{
Assessment of Undiscovered Oil and Gas Resources of the Sirte and Pelagian Basin Provinces of Libya, Tunisia, Malta, and Italy, 2019
}

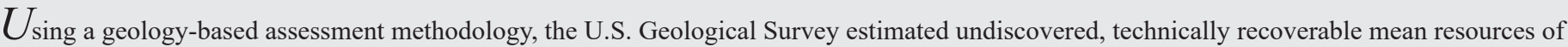
16.4 billion barrels of oil and 106.3 trillion cubic feet of gas in the Sirte and Pelagian Basin Provinces of Libya, Tunisia, Malta, and Italy.

\section{Introduction}

The U.S. Geological Survey (USGS) quantitatively assessed the potential for undiscovered, technically recoverable conventional oil and gas resources in the Sirte and Pelagian Basin Provinces of Libya, Tunisia, Malta, and Italy (fig. 1). The Sirte and Pelagian Basin Provinces encompass a series of generally northwest-southeast trending horsts (or platforms) and grabens (or troughs) representing a polyphase history of rifting, subsidence, and postrift thermal sag beginning in the Triassic and continuing into the Neogene (Montgomery, 1994; Abadi and others, 2008; Badalini and others, 2009; Fiduk, 2009; Mriheel, 2015). The extent and orientation of rifts, magnitude of subsidence related to rifting events, and postrift deposition were the result of the diachronous opening of the Atlantic and Tethys Oceans, temporal variations in the movement of the African and Apulian Plates and Calabrian arc, and transpressional to transtensional motion along regional strike-slip faults in northernmost Africa (Fiduk, 2009; Hassan and Kendall, 2014).

Major petroleum source rocks deposited in the Sirte and Pelagian Basins reflect a complex tectonic and eustatic history and include the Lower Cretaceous Nubian Sandstone; the Upper Cretaceous Sirte, Rachmat, and Etel Shales in the Sirte Basin (and their Paleocene equivalents in the Pelagian Basin); and the Eocene Bou Dabbous Formation (or Bilal Shale) in the Pelagian Basin (Gumati and Schamel, 1988; Affouri and Montacer, 2014; Hassan and Kendall, 2014; Hrouda and Abdulhafied, 2019). Silurian source rocks have been reached by drilling in the Tunisian offshore part of the Pelagian Basin, and the Silurian source rocks are known to exist immediately to the south in the Ghadames Basin (Wang and others, 2019). Spatial variations in subsidence, thickness of synrift fill, heat flow, and Neogene uplift and erosion resulted in a complex pattern of source-rock thermal maturity across the study area (Montgomery, 1994). However, the extent of gas occurrence appears to be more extensive in the offshore compared to the onshore portions of the Sirte and Pelagian Basins (Futyan and Jawzi, 1996; Klett, 2001).

\section{Total Petroleum Systems and Assessment Units}

The USGS defined three total petroleum systems (TPS) and five assessment units (AU) within these systems: (1) Sirte Basin MesozoicPaleogene TPS with the Sirte Basin Mesozoic Onshore Conventional Oil and Gas AU and Sirte Basin Mesozoic Offshore Conventional Oil and Gas AU, (2) Pelagian Basin Mesozoic-Paleogene TPS with the Pelagian Basin Mesozoic Conventional Oil and Gas AU and Pelagian Basin Bou Dabbous Conventional Oil and Gas AU, and (3) Pelagian-Sirte Basins Silurian TPS with the Pelagian-Sirte Basins Silurian Offshore Conventional Gas AU. Assessment input data are summarized in table 1.

The geologic model for the Sirte Basin Mesozoic-Paleogene TPS and the Pelagian Basin Mesozoic-Paleogene TPS is for oil and gas to have been generated from organic-rich shales in the Paleogene with peak oil generation possibly in the late Paleogene to Neogene (Hassan and Kendall, 2014) and oil generation from the Eocene Bou Dabbous Formation in the Miocene to Pliocene. The geologic model for the Pelagian-Sirte Basins Silurian TPS is dependent on Silurian organicrich marine shales to have been preserved in the continental margin offshore (Montgomery, 1994). If present, Silurian shales reached thermal generation for oil and gas possibly in the Mesozoic, and Cenozoic burial resulted in the cracking of oil to gas. Oil and gas from all source rocks migrated into a spectrum of conventional structural and stratigraphic traps and reservoir types throughout the Sirte and Pelagian Basins (Klett, 2001; Fiduk, 2009; Whidden and others, 2011).

\section{Undiscovered Resources Summary}

The USGS quantitatively assessed undiscovered conventional oil and gas resources in five assessment units (table 2). For undiscovered, technically recoverable conventional oil and gas resources, the mean totals are 16,357 million barrels of oil (MMBO), or 16.4 billion barrels of oil, with an F95-F5 fractile range from 8,445 to 27,027 MMBO; 106,311 billion cubic feet of gas (BCFG; associated), or 106.3 trillion cubic feet of gas, with an F95-F5 fractile range from 49,916 to 185,070 BCFG; and 1,614 million barrels of natural gas liquids (MMBNGL), or 1.6 billion barrels of natural gas liquids, with an F95-F5 fractile range from 763 to 2,830 MMBNGL. Of the mean total conventional oil resources of 16,357 MMBO, about 9,569 MMBO, or 59 percent, is estimated to be in the onshore portion of the Sirte Basin.

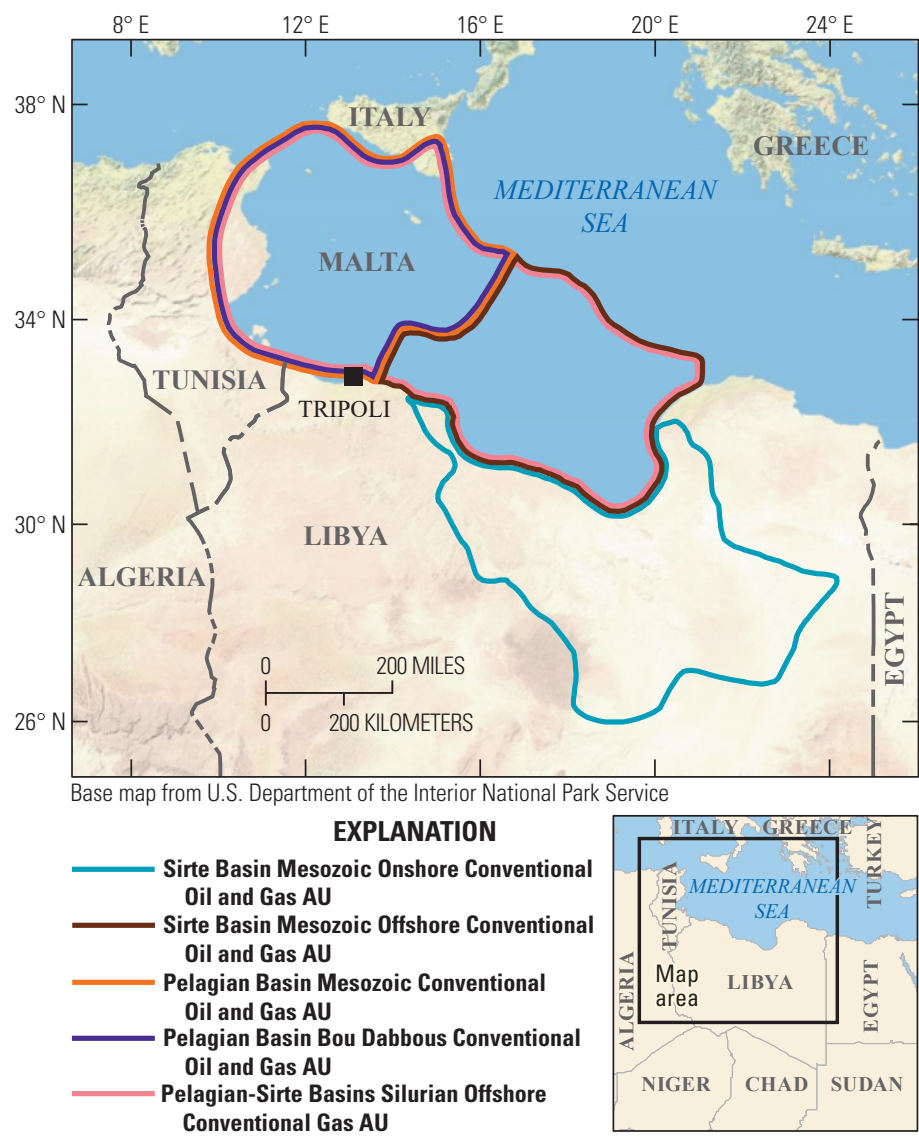

Figure 1. Map showing five conventional assessment units (AUs) in the Sirte and Pelagian Basin Provinces of Libya, Tunisia, Malta, and Italy. 
Table 1. Key input data for five conventional assessment units in the Sirte and Pelagian Basin Provinces of Libya, Tunisia, Malta, and Italy.

[AU, assessment unit; MMBO, million barrels of oil; BCFG, billion cubic feet of gas. Shading indicates not applicable]

\begin{tabular}{|c|c|c|c|c|c|c|c|c|}
\hline \multirow{2}{*}{$\begin{array}{l}\text { Assessment input data- } \\
\text { Conventional AUs }\end{array}$} & \multicolumn{4}{|c|}{ Sirte Basin Mesozoic Onshore Conventional Oil and Gas AU } & \multicolumn{4}{|c|}{ Sirte Basin Mesozoic Offshore Conventional Oil and Gas AU } \\
\hline & Minimum & Median & Maximum & Calculated mean & Minimum & Median & Maximum & Calculated mean \\
\hline Number of oil fields & 1 & 400 & 900 & 413.5 & 1 & 120 & 360 & 127.6 \\
\hline Number of gas fields & 1 & 100 & 300 & 106.3 & 1 & 240 & 480 & 245.9 \\
\hline Size of oil fields (MMBO) & 1 & 5 & 1,500 & 23.1 & 5 & 10 & 2,500 & 37.5 \\
\hline Size of gas fields (BCFG) & 6 & 30 & 2,000 & 69.6 & 30 & 60 & 9,000 & 177.1 \\
\hline AU probability & 1.0 & & & & 1.0 & & & \\
\hline \multirow{2}{*}{$\begin{array}{c}\text { Assessment input data- } \\
\text { Conventional AUs }\end{array}$} & \multicolumn{4}{|c|}{ Pelagian Basin Mesozoic Conventional Oil and Gas AU } & \multicolumn{4}{|c|}{ Pelagian Basin Bou Dabbous Conventional Oil and Gas AU } \\
\hline & Minimum & Median & Maximum & Calculated mean & Minimum & Median & Maximum & Calculated mean \\
\hline Number of oil fields & 1 & 60 & 180 & 63.8 & 1 & 60 & 120 & 61.5 \\
\hline Number of gas fields & 1 & 100 & 300 & 106.3 & 1 & 80 & 160 & 82.0 \\
\hline Size of oil fields (MMBO) & 5 & 10 & 500 & 19.3 & 5 & 10 & 100 & 12.8 \\
\hline Size of gas fields (BCFG) & 30 & 60 & 5,000 & 139.0 & 30 & 60 & 2,500 & 109.2 \\
\hline AU probability & 1.0 & & & & 1.0 & & & \\
\hline \multirow{2}{*}{$\begin{array}{c}\text { Assessment input data- } \\
\text { Conventional AU }\end{array}$} & \multicolumn{4}{|c|}{ Pelagian-Sirte Basins Silurian Offshore Conventional Gas AU } & & & & \\
\hline & Minimum & Median & Maximum & Calculated mean & & & & \\
\hline Number of gas fields & 1 & 120 & 480 & 132.3 & & & & \\
\hline Size of gas fields (BCFG) & 30 & 60 & 6,000 & 149.3 & & & & \\
\hline AU probability & 0.7 & & & & & & & \\
\hline
\end{tabular}

Table 2. Results for five conventional assessment units in the Sirte and Pelagian Basin Provinces of Libya, Tunisia, Malta, and Italy.

[MMBO, million barrels of oil; BCFG, billion cubic feet of gas; NGL, natural gas liquids; MMBNGL, million barrels of natural gas liquids. Results shown are fully risked estimates. F95 represents a 95-percent chance of at least the amount tabulated; other fractiles are defined similarly. Fractiles are additive under the assumption of perfect positive correlation. Shading indicates not applicable]

\begin{tabular}{|c|c|c|c|c|c|c|c|c|c|c|c|c|c|c|}
\hline \multirow{3}{*}{$\begin{array}{l}\text { Total petroleum systems } \\
\text { and assessment units (AUs) }\end{array}$} & \multirow{3}{*}{$\begin{array}{c}\text { AU } \\
\text { prob- } \\
\text { ability }\end{array}$} & \multirow{3}{*}{$\begin{array}{l}\text { Accu- } \\
\text { mulation } \\
\text { type }\end{array}$} & \multicolumn{12}{|c|}{ Total undiscovered resources } \\
\hline & & & \multicolumn{4}{|c|}{ Oil (MMBO) } & \multicolumn{4}{|c|}{ Gas (BCFG) } & \multicolumn{4}{|c|}{ NGL (MMBNGL) } \\
\hline & & & F95 & F50 & F5 & Mean & F95 & F50 & F5 & Mean & F95 & F50 & F5 & Mean \\
\hline \multicolumn{15}{|c|}{ Sirte Basin Mesozoic-Paleogene Total Petroleum System } \\
\hline \multirow{2}{*}{ Sirte Basin Mesozoic Onshore Conventional Oil and Gas AU } & \multirow{2}{*}{1.0} & Oil & 5,414 & 9,235 & 14,891 & 9,569 & 4,738 & 9,045 & 16,191 & 9,562 & 68 & 134 & 251 & 143 \\
\hline & & Gas & & & & & 3,438 & 6,930 & 13,007 & 7,404 & 25 & 54 & 111 & 59 \\
\hline \multirow{2}{*}{ Sirte Basin Mesozoic Offshore Conventional Oil and Gas AU } & \multirow{2}{*}{1.0} & Oil & 1,957 & 4,405 & 8,829 & 4,772 & 2,131 & 5,181 & 11,224 & 5,728 & 31 & 77 & 172 & 86 \\
\hline & & Gas & & & & & 26,105 & 42,193 & 65,295 & 43,514 & 238 & 417 & 696 & 436 \\
\hline \multicolumn{15}{|c|}{ Pelagian Basin Mesozoic-Paleogene Total Petroleum System } \\
\hline \multirow{2}{*}{ Pelagian Basin Mesozoic Conventional Oil and Gas AU } & \multirow{2}{*}{1.0} & Oil & 563 & 1,149 & 2,179 & 1,231 & 403 & 899 & 1,859 & 984 & 4 & 11 & 23 & 12 \\
\hline & & Gas & & & & & 6,722 & 13,764 & 26,138 & 14,772 & 194 & 410 & 808 & 443 \\
\hline \multirow{2}{*}{ Pelagian Basin Bou Dabbous Conventional Oil and Gas AU } & \multirow{2}{*}{1.0} & Oil & 511 & 765 & 1,128 & 785 & 983 & 1,523 & 2,318 & 1,570 & 17 & 30 & 51 & 31 \\
\hline & & Gas & & & & & 5,396 & 8,677 & 13,412 & 8,941 & 186 & 341 & 588 & 358 \\
\hline \multicolumn{15}{|c|}{ Pelagian-Sirte Basins Silurian Total Petroleum System } \\
\hline Pelagian-Sirte Basins Silurian Offshore Conventional Gas AU & 0.7 & Gas & & & & & 0 & 13,413 & 35,626 & 13,836 & 0 & 40 & 130 & 46 \\
\hline Total undiscovered conventional resources & & & 8,445 & 15,554 & 27,027 & 16,357 & 49,916 & 101,625 & 185,070 & 106,311 & 763 & 1,514 & 2,830 & 1,614 \\
\hline
\end{tabular}

\section{References Cited}

Abadi, A.M., van Wees, J.-D., van Dijk, P.M., and Cloetingh, S.A.P.L., 2008, Tectonics and subsidence evolution of the Sirte Basin, Libya: American Association of Petroleum Geologists Bulletin, v. 92, no. 8, p. 993-1027.

Affouri, H., and Montacer, M., 2014, Organic matter appraisal of the lower Eocene (Ypresian) Bou Dabbous Formation in Tunisia: Arabian Journal of Geoscience, v. 7, p. 5509-5542.

Badalini, G., Redfern, J., and Carr, I.D., 2009, A synthesis of current understanding of the structural evolution of North Africa: Journal of Petroleum Geology, v. 25, no. 3, p. 249-258.

Fiduk, J.C., 2009, Evaporites, petroleum exploration, and the Cenozoic evolution of the Libyan shelf margin, central North Africa: Marine and Petroleum Geology, v. 26, no. 8, p. 1513-1527.

Futyan, A., and Jawzi, A.H., 1996, The hydrocarbon habitat of the oil and gas fields of North Africa with emphasis on the Sirt Basin, in Salem, M.J., El-Hawat, A.S., and Sbeta, A.M., eds., Geology of the Sirt Basin, v. 2: Amsterdam, Elsevier, p. 287-308.

Gumati, Y.D., and Schamel, S., 1988, Thermal maturation history of the Sirte Basin, Libya: Journal of Petroleum Geology, v. 11, no. 2, p. 205-218

Hassan, H.S., and Kendall, C.C.G., 2014, Hydrocarbon provinces of Libya-A petroleum system study, chap. 4 of Marlow, L., and Yose, L., eds., Petroleum systems of the Tethyan region: American Association of Petroleum Geologists Memoir No. 106, p. 101-141.
Hrouda, M.S., and Abdulhafied, Z.A.B., 2019, Hydrocarbon potential of the lower Eocene formations in Sabratah Basin, north west offshore Libya: American Association of Petroleum Geologists, Search and Discovery Article No. 11184, 8 p., accessed March 12, 2019, at http://www.searchanddiscovery.com/pdfz/documents/2019/11184hrouda/ndx_hrouda.pdf.html.

Klett, T.R., 2001, Total petroleum systems of the Pelagian Province, Tunisia, Libya, Italy and Malta-The Bou Dabbous Tertiary and Jurassic-Cretaceous Composite: U.S. Geological Survey Bulletin 2202-D, 27 p.

Montgomery, S., 1994, Sirte Basin, north-central Libya_-Prospects for the future: Petroleum Frontiers, v. 11, no. 1, 92 p.

Mriheel, I.Y., 2015, Paleogeography and sedimentation history of the western Libya offshore, central Mediterranean: American Association of Petroleum Geologists, Search and Discovery Article No. 10699, 10 p., accessed February 28, 2019, at http://www. searchanddiscovery.com/pdfz/documents/2015/10699mriheel/ndx_mriheel.pdf.html.

Wang Zhaoming, Shi Buqing, Wen Zhixin, Tong Xiaoguang, Song Chengpeng, He Zhengjun, and Liu Xiaobing, 2019, Shale oil and gas exploration potential in the Tannezuft Formation, Ghadames Basin, North Africa: Journal of African Earth Sciences, v. 153, p. 83-90.

Whidden, K.J., Lewan, M.D., Schenk, C.J., Charpentier, R.R., Cook, T.A., Klett, T.R., and Pitman, J.K., 2011, Assessment of undiscovered oil and gas resources of Libya and Tunisia, 2010: U.S. Geological Survey Fact Sheet 2011-3105, 2 p.

Differences in the spelling of the Sirte (Sirt) Basin reflect the individual author's usage.

\section{Sirte and Pelagian Basin Provinces Assessment Team}

Christopher J. Schenk, Tracey J. Mercier, Marilyn E. Tennyson, Phuong A. Le, Janet K. Pitman, Ronald M. Drake II, Michael E. Brownfield, and Thomas M. Finn

\section{For More Information}

Assessment results are also available at the USGS Energy Resources Program website at https://energy.usgs.gov. 